\title{
A Visual Narration of Hells in Buddhism and Islam
}

\author{
Ary Budiyanto
}

Indonesian Consortium for Religious Studies (ICRS) Yogyakarta

yrelief@yahoo.com

Abstract: The visualization of the Hell's Tortures both in Buddhism and in Islam is exactly similar. However, their kind of 'theological' tendencies may result different outcome. By comparing the visual narration of the Buddhism and Islamic comic books dealing with hell illustrations, I made an 'imaginary' dialogue between the concept and visuality of hells tortures that exist in both traditions, and see the impact on how far a sincere dialogue could be achieved in these two religious people. During this comparison, I found that both Buddhism and Islam in Java had ever made such an interesting dialogue.

Keywords: Hell tortures, Islam-Buddhism comparison, encounter of JavaIndonesia

Abstrak: Konsep neraka Islam itu memiliki kemiripan dengan agama Buddha, meskipun konsep teologis keduanya memiliki hasil yang berbeda. Dengan melakukan perbandingan visual antara buku komik Islam dengan ilustrasi Buddha, tulisan ini mencoba membuat dialog imajinasi antara konsep dan gambaran neraka yang ada dalam dua tradisi tersebut dan akan melihat implikasinya. Ditemukan pula bahwa agama Buddha dan Islam di Jawa, dalam membuat gambaran itu, ternyata menjadi dialog yang menarik.

Kata Kunci: Siksa neraka, perbandingan Islam-Budha, pertemuan JawaIndonesia 


\section{Introduction}

For the 'ordinary' Muslim, the fate of human being is teleological, that is after living in this world human may only have two choices of living in the hereafter-life: in the hells or heavens. By living according to their religious virtues, Muslim believe that they will go to heavens but others who are not living according the Islamic virtues will certainly go directly to hells. Even for whom they have already stated that they are Muslim but not lived according to his/her Islamic way of life will be dragged into the deepest and terrible hell called the Jahanam hell. The longing place that all ordinary Muslims want mostly is called heaven realm. This is the different to what most Buddhists believe. A Buddhist believes that hells and heavens are realms that individuals have to experienced for what had they done in their worldly life, but in fact according to Buddhism those are 'places' that still in causal effects laws that is where karmic law (a state of samsara) still operates. Even in Buddhism, this realm of hells is also known as the Yama's heaven. ${ }^{1}$ One should recalls that the greatest aims of life according to Buddhism is attaining nibbana, a state of blissfulness and enlightenment of the Truth, that somewhat has certain parallel with Islamic Sufism teaching on fan $\vec{a} .^{2}$ This teleological conception different on hells, as we will see through this discussion below, will bring consequences on how this two believers communicate to one and another. Indeed, through this discussion we will know what kind of dialogue that they will take.

To make us clear of what the hells is about I make several sections of discussion. Throughout this discussion we will look for the historical and theological background of the tales of hells in both of these two traditions and its relation to the Javanesse version up to this present day. The first section, we will see the historical records of hells tales in Java, Indonesia. The second section we will explore the tales of hells in Buddhism tradition, and along with it is description of Islamic hells from the Qur'ān and Hadīths ${ }^{3}$ to clarify the explanation. In the next section, we will look at the resembles of these two traditions from its sample of the visual narration from the Islamic comic book of Siksa Neraka and the Japanese Hell Scrolls from Matsunaga book. Finally, it will close the discussion with reflection. 


\section{The Tales of Hells In Java: Historical Notes}

Perhaps, the oldest tale of Indonesian Buddhism hells is found from the era of Singhasari Kingdom of Java. It was the Kunjarakarna Dharmakathana book written by a poet known as Mpu Dusun (lived in the era of Singhasari to the early of Majapahit Kingdom circa 12$14^{\text {th }} \mathrm{CE}$ ). According to the Buddhist and historian scholars, this book is the Mahayanist that teaches the purification way according to the Bodhicitta Mahayana teaching. Archeologist believe that this is the text was used on the relief-bas of Candi Jago (also known as Jajaghu temple) of Malang, Eastern Java. The Jago temple complex is a burial plot monument for the Wisnuwardhana, a king of Singahsari. The Kunjarakarna Dharmakathana tells us about the journey of Kunjarakarna into hells realm in order to learn the great teaching of Vairocana Buddha. During his journey to the hells he found an empty cauldron hell that is prepare for his beloved and generous friend, King Purnawijaya. The Yama King said that it is because the Purnawijaya does not follow the teaching of Vairocana Buddha. ${ }^{4}$ According to the archeologist and historian, the version of hells depiction in Kunjarakarna text was probably based on Saddharmasmriti-upasthâna text (Recalling the True Doctrine of Dharma) by Gautama Prajnnâruci, India (ca. 4-5 CE.)

Daigan and Alicia Matsunaga's book, The Buddhist Concept of Hell, is a study on Chinese and Tibetan text that exist in Japan Chenfa-nien-ch'u-ching or Shôbônenjo-kyô (Jp.) within Taisho Tripitaka Vol.17 pp. 1-379. ${ }^{5}$ Even though there are many differences with the Kunjarakarna, the systematic depiction of these Eight Levels of Hells, and why people drag into it, is exactly similar. This text according to the Buddhist historian is very popular among the Japanese Pure Land thougth Buddhism in twelveth century or even before perhaps. ${ }^{6}$ Within this book of Matsunaga I came across with several illustration of hells from famous Japanese Hell Scrolls that here I will use it for comparison with Indonesian Islamic hells comics' book.

No doubt, that it seems this tales of hells text was very popular in Eastern Asia and Southeast Asia Buddhism, at least up to $12^{\text {th }}$ $14^{\text {th }} \mathrm{CE}$. Even the remnant of this Hindust-Buddhist ${ }^{7}$ hells is still acknowledged by the Indonesian in the form of Wayang ${ }^{8}$ comics book 
especially in R.A. Kosasih's comic book, which entitled Pandawa Seda (the Death of Pandawa) ${ }^{9}$ circa 1954-1960's. ${ }^{10}$ this comic book was still popular in 1970's when the Islamic Siksa Neraka comic were getting its popularity. In this Pandawa Seda story it told that they experiencing both hells and heavens realm just as their brothers enemy, the Kurawas. This typical narration is in line with the teaching of Karmawibangha sutra.

Up to the present, this tale of "Journey to Hells" and its illustrations is still popular in Buddhist community of Indonesian Chinese. It is easy to find the book entitled Melawat Ke Alam Neraka Kisah Kejadian Nyata (Journey to the Hells World, a real story) in any Kelentheng or Vihara, ${ }^{11}$ this book is translation from the Ti Yi You $C i$ text. It tells the journey of Rev. Yan San Sheng in 1976-1977(8) into hells worlds under the decree of Heavenly King Giok Tee (Jade Emperor) and under the spiritual guidance of Bodhisattva Chit Kung (Ci Hoet). Rev. Yan San Sheng lived in Vihara Sheng Shian Tian in the city of Tai Chung (it is not clear whether it is in Taiwan or Mainland China). This visual depiction is also found as murals at the walls of Kelenteng Vihara Langit Bumi (Heaven and Earth Shrine), Singkawang East Kalimantan Indonesia. ${ }^{12}$

It seems, during the Islamic era of Java, there was a great dialogue between the Islamic Sufi traditions with the Javanese Bodhisattva tradition; here the Prophet Isa (Jesus) journey into hells and saving the un-Islamic soul is a common theme. The $19^{\text {th }}$ century work of Batavian Muslim of Syair Alif Ba Ta (the Alif Ba ta poet) by Haji Zainal Abidin also depicting the prophet Isa and the king soul in hells. ${ }^{13}$ Wierengga believes that this text is the source of adaptation for the famous Javanese Poet Centhini, in this poet it is known as Kitab Mamahi (or Tamai book). There is also other Javanese version of it known as Serat/Suluk Pathak (Tales of the Skull poet), it is believed by Wierengga and others that Suluk Pathak, now it is kept in Sono Budoyo Museum of Yogyakarta, is the adaptation from the malay Hikayat of Raja Jumjumah poets. ${ }^{14}$ The story is about the King of Syria soul that cannot enter heaven because he was not Muslim yet, and with the prayer of Prophet Isa, he will be born again in the world as a Muslim in order to ease his way entering to heaven. ${ }^{15}$ The tale of 
hell torture also found in the Syair Neraka (The Poets of Hells), Syair Adzab dalam Neraka (the Poets of Hells tortures), Syair Kanak-Kanak (children poets), and genre of sakaratul maut (near-dying) stories. ${ }^{16}$ That is why the adoption of a Malay Sanskrit word notion of Jannah or heaven as Swarga and Nar or hell as Neraka was existed.

\section{Buddhist Hells and Its Islamic Resemblances}

My childhood memory was stunning when the first time I read a quotation from Ksitigarbha Bodhisattva Sutra ${ }^{17}$ and its similarity with the Islamic tradition. To make us clear, here I paste the depiction of the hells according to Ksitigarbha Bodhisattva Sutra and added in the footnotes the resemblance depiction of hell in Islamic tradition:

Ksitigarbha Bodhisattva replied: "My compassionate One, under the supernatural powers of the Buddha and your kind support, I now give you the names of Hells and the kinds of punishment for sinners in brief. ${ }^{18}$

1. The Great Avici Hell at the East of the Mahachakravala Mountain, which is extremely cold ${ }^{19}$, for there is neither light of the sun nor the moon, there is a great Hell by the name of Great Avici. Punishments in this Hell comprise of pain, form, birth and death. Such punishments continue without intermission.

3. Hell of Four Corners Where hot and burning iron-walls surround this Hell and with flames of fire falling on the sinners, like heavy rain-drops. After the sinners are burnt to death, they are reborn for further sufferings.

5. Hell of Burning Arrows Where millions of Burning Arrows pierce through the sinners' hearts and bodies.

6. Hell of Crushing Mountains Where sinners will be crushed to pieces between two Mountains.

9. Hell of Burning Iron-Beds Where sinners bodies are placed on these Beds to be burnt to death. ${ }^{20}$

11. Hell of Burning Iron-Clothing Where sinners are wrapped up by these burning Iron-Clothing. ${ }^{21}$

12. Hell of Thousands of Burning Iron-swords Where sinners are forced to lie on them which pierce through their bodies. Knives are also seen flying from the air, hitting the sinners' bodies and 
cutting them to pieces.

14. Hell of Molten Brass Where sinners have Molten Brass poured into their mouths. ${ }^{22}$

16. Hell of Burning Flames Where sinners bodies are burnt by the Flames falling on them like rain-drops without any chance for them to escape.

18. Hell of Iron-Saws Where the heads of sinners are sawed. ${ }^{23}$

20. Hell of Iron Eagles Where sinners' eyes are pecked by Iron-Eagles.

23. Hell of Iron-Hammers Where sinners are smashed by the IronHammers. ${ }^{24}$

25. Hell of Wailing Where sinners are thrown into the burning tanks (cauldron hell? author) with molten iron and they wail on account of severe pain.

28. Hell of Brass Locks Where sinners are locked against the IronMountain and made to run. ${ }^{25}$

32. Hell of Fire Mountains Where sinners are forced to walk between them and be crushed into ashes.

37. Hell of Fire Saws Where sinners' bodies and teeth are sawed. And again, there is a Hell of iron-trees with sharp thorns where sinners are dragged against the burning thorns. ${ }^{26}$

There is a Hell of iron-wolves, which either run after or stamp on sinners' bodies, and even bite them to pieces.

"In some of the Hells, there are burning spears, which pierce through the suffering sinners. In some of the Hells, the hands and feet of sinners are made to hold or walk on burning irons. In some of the Hells, the bodies of sinners are urled around by iron snakes. ${ }^{27}$

These various name and depiction of the Buddhist hells commonly listed in eight level of Hells realm, such as in Matsunaga book (1972) and Kunjarakarna in Sukarto (1988) and A. Teeuw Robinson (1981). Those hells and its dwellers are:

The first hell is the realm of murderers. Here suffer those who kill for pleasure or desire. It is the Hell of Repetition (Samjiva). The next destination is known as Black Rope Hell (Kala Sutra). The point is made that, though people may commit crimes as members of a group, they must suffer the consequences as individuals. 
Certain types of killing, or stealing along with sexual indulgence, lead to the Crowded Hell (Samghata). Having improper attitudes to physical love leads to Fire-jar Hell where self-proclaimed monks, or those who misuse their office are tormented with fire at the organ that caused the wrongful behaviour. Next is Screaming Hell (Raurava) is the destination for those who misuse intoxicants. The Great Screaming Hell (Maha Rauvara) is the place for those whose misdeeds are via sound or the voice, generally. Those who hold false views can experience the Hell of Burning Heat (Tapana). They who deny that a law of cause and effect [karma] is in operation and hence, by extension, deny the existence of good and evil can know the Diamond-beak Hornet Hell. ... The seventh Hell is related to the sexual deflement of religion. It is called Burning Hell of String-like Worms (Pratapana). Those who seduce nuns or monks are tied up and pegged to the ground where a demons stuffs worms up their anus which travel up through the alimentary canal eating everything in their way until they crack their way out of the head of the sinner. The last hell is the Hell of No Interval (Avici). This is the destination of those committing the 5 most serious crimes: 1. pre-meditated murder of one's mother 2. pre-meditated murder of one's father 3. pre-meditated evil intent to harm an Enlightened One and to rejoice in that action 4. pre-meditated intent to harm the Buddhist community or sangha 5. pre-meditated murder of arhats or bodhisattvas. " 28

Meanwhile, according to Islamic teaching from al-Qur'ān and Hadīth, as in Abdullah (2006) and Umar (1978), ${ }^{28}$ all non Muslim peoples even they are never commited sin according to Islamic teaching but they do not believe in Allah and its Prophet will certainly enter to the Muslim's hells. Thus, the story of non-Muslim soul as King Syria, in which he will be born again and embraced Islam is not in the ordinary Islamic notion. However, the possibility of Muslim or non-Muslim hell dwellers might get a wild card from the hells tortures is possible. This possibility is based on the exegesis of some Sufist ulamas, ${ }^{29}$ which is interpreting the verses:

"As for those who will be wretched (on that day) they will be in the Fire; sighing and wailing will be their portion therein. Abiding there so long as the heavens and the earth endure save for that 
which thy Lord willeth. Lo! thy Lord is Doer of what He will." (QS. Hüd/11: 106-7)

\section{Hells in the Buddhism and Islamic Visualization}

In order to get the understanding of the visual narration of hells in Islam and Buddhism, I have collected a comic book on Siksa Neraka by MB. Tjutjuk Wibisono, MB. Rahimsyah, or MB. Rahimsyah AR and Irsyadul Imam, or Ema Wardana. Here, I found that there are two versions of Siksa Neraka comics. First version stated that there are eight levels of hells: 1. Jahanam, 2. Jahīm, 3. Hāwiya, 4. Wayl, 5. Sa īr, 6. Lazāa, 7. Saqar, and 8. Huṭama. Yet, the second version stated that there are only seven evel of hells. The seven levels of hells in Islam are the common acceptance tradition even though there many name of hells 'valleys' that also known by the tradition (see Abdullah, 2006: 45). Those seven levels of hells are: Jahannam [QS. al-Naba'/78: 21], Lazā [QS. al-Ma'̄rij/70: 15-16], al-Hutama or Crusher, which Smashes or Breaks to Pieces [QS. al-Humazah/104: 4-7], Sa îr or the Burning Fire [QS. al-Syu'arā/42: 7] Saqar [QS. al-Muddatstsir/74: 26-29] al-Jahim (The Fierce Fire) [QS. al-Syu 'arā/26: 91], and alHāwiyah (The Pit) [QS. al-Qāri'ah/101: 8-11; QS. al-Anfāl/8: 5051] (Abdullah 2006; Umar, 1978). Regardless the number levels and names, there is difference between Buddhist hells and Islamic hells in terms of its geography. Buddhist notion of hell place is always referring to the 'under' world, whilst Islam states that hell is side by side with heaven (QS. al-A'raf/7: 46). In addition, in Islamic comic visualization there are 'demons' which are tortured along with the sinner by the unseen 'angel', whilst in Buddhism only human is tortured. In fact, the Yama King of Buddhism could be similarly seen as the angel of Malik (QS. al-Zukhruf/43: 77) and the scarry and fierceful 'demons' who are torturing the sinner exactly similar with the angel of Zabaniah (QS 96: 18), in which its 'demonic' appearances is depicted in QS. al-Tahrīm/66: 6. ${ }^{30}$ Now let us see some of the visualization of hells between Buddhism and Islam. The arrangement is the first layer is from Japanese Buddhist scroll from Matsunaga book, second layer is Islamic images from Siksa Neraka comic.

From some images above, we know now that the visualization of 
hells tortures of Islam and Buddhist tradition is had a lot of similarity. Even, in the Sufist tradition the belief that hells and heavens are just a projection of our mental actions (Rahmat, 1996) is much common as in Buddhist. Nevertheless, nowadays the interpretation and depiction of non-Muslim soul could be reborn again and becoming Muslim such as in $14^{\text {th }}$ century Sufism texts in Malay world and Serat Pathak of Java seems out of the modern modern discourse.

\section{So, What We Should Do?}

Form the text and visualization of 'ordinary' Islamic hell tortures it is clear and simple that all of the past, present and future people who do not believe in Allah and its Prophet Muhammad are directly will going to Islamic hells. The notion of the 'second' chance for the good people from the non-Muslim to be born again as Muslim is not there anymore in living Javanese Muslim tradition today. Even the popular understanding of who is the dweller of the seven levels of Islamic hells is obviously depicted in this comic as related to their religious belief affiliation rather than because of their conduct such as in Buddhism. It is stated in this comic that the first level of hell is for the follower of the Prophet Muhammad who commited sins. Second level is for the Nashara or Christians. Third level is for the Jews. Forth level is for the star worshipers or Sabeans. Fifth level is for the polytheist (mushrik), next level is for the genies (jin), and finally, the seventh level or Jahanam is for the hypocrites or munafiq.

Looking at today Islamic doctrinal tradition obviously no one in this world might be able to escape from the threat of Muslim hells even though they are good toward others and to nature during in their life. ${ }^{31}$ This is absolutely in contrast with the Buddhist believes that sees heaven or hell is sprung from the karmic consequences of their previous worldly actions. Actually, there are verses that are in tune with this Buddhist view, thus we could read it in QS. al-An'ām/6: 70, ${ }^{32}$ QS. al-Nisā/4: 97, ${ }^{33}$ QS. al-Anfāl/8: 50-51. ${ }^{34}$ Nevertheless, both tradition agree and emphasize that the best chance and opportunity to do a good deeds and repent from our sins is here and now during in this worldly life.

The care of Muslim is to propagate the messages of Islam in oder 
their kindness non-Muslim brothers save from their' Hells. As we already know, the Sufi in Java has already made an admirable solution by giving people of non-Muslims individual a second chance, by offering a rebirth as Muslim. Yet, it could be interpreted further ironically as since this present life now is their rebirth so there is no another rebirth. Meaning the non-Muslim should accept Islam or going to their hells, cause they know that any of the good deeds that non-Muslim did is useless and cannot save them from the Muslim's hells. ${ }^{35}$ In other way around, Buddhist hells also warns to Muslim and others non-Buddhist that they will enter Buddhist hells if they committed sin to what Buddhist has ordered not to do. Thus, it seems the positive dialogue between Buddhism and Islam in Java is being challenged with the more conservative perspective. Nevertheless, Chinese Buddhist community in Java still has a positive perspective toward other religions related to the meaning of hells tortures. Here in book of Melawat ke Alam Neraka Kisah Kejadian Nyata by Yang San Sheng (2005) we see that hells is a universal place for the sinners. It is told that in heaven of Yan San Sheng, witnessing during the celebration of this book of Journey to the Hells, he met representator from all of the prophets, the good believers, gods, angels, advanced disciples, from Buddhism, Christians, Islam, Hinduism, Confucianism, and even a new religious movement.

\section{Conclusion}

As Muslim always pray with the supplication prayer above then it is clear that they have to propagate Islam to others for they know and care of the dreadful fate of the others souls if they not accepting Islam. ${ }^{36}$ Whilst Buddhist believes that only they who committed sins according to their dharma will enter hells. So what we should do now? Thus, based on the texts of their teachings the Buddhist might state to Muslim, that they know and responsible to what they have chose in this life including not embracing Islam. Moreover, if they are entering hell of Islam because of that, it means they got their karmic retribution, and hoping they will rebirth again to fix their karma. For the Muslim, excessive caring attitude toward others would break their God's decree and any difference in this universe is God's 
will (QS. al-Hujurāt/49: 13). In fact, good Muslim knows that there is no compulsion in embracing religion (QS. al-Baqarah/2: 256). Moreover, God reminds the Muslim that the limit of theological dialogue is coerce to the saying that "Unto you your religion, and unto me my religion” (QS. al-Kāfirūn/109: 6). Therefore, what we all should do in this world is "vie with one another in good works." (QS. al-Baqarah/2:148).

\section{Endnotes:}

1 The notion of hell as Yama's heaven is in Prabidhana Sutra chapter Kstigarbha Bodhisattva, see http://www.avg.or.id/kisah.php?id=47 (accessed Nov 27, 2008).

${ }^{2}$ Fanä is a state of a mystical annihilation of self, union with God (the Great Universal Consciousness).

3 Hadith is a collection of the Prophet's sayings.

${ }^{4}$ See also Atmodjo M.M. Sukarto, Dosa dan Siksa Neraka Menurut Naskah Kunjarakarna Dharmakatana (paper at Lembaga Javanologi Yogyakarta 39, 1988); A.Teeuw and S.O.Robinson, Kunjarakarna Dharmmakathana: Liberation through the law of Buddha (Leiden: KITLV Press, 1981); and T.M. Hunter Jr., "The Aridharma Reliefs of Candi Jago" in Society and Culture of Southeast Asia: Continuities and Change, pp. 61-101 (New Delhi: International Academy of Indian Culture and Aditya Prakashan, 2000).

5 Daigan Matsunaga and Alicia Matsunaga, The Buddhist Concept of Hell (New York. Philosophical Library Inc.,1972).

6 The oldest depiction of hells in Java Indonesia is probably crafted in the based wall reliefs of Borobudur Temple within the Karmawibangha scenes $\left(8^{\text {th }}-9^{\text {th }}\right.$ $\mathrm{CE}$ ); see this Borobudur notion of hell and heaven at http://www.borobudur. tv/karma_1.htm. (accessed Nov 27, 2008) In http://www.onmarkproductions. com/html/oni-demons.shtml, we read that this Hell Scroll, is probably have been made during the time of Emperor Goshirakawa (1127-92, r. 1155-58) and even it was popular in the latter part of the Heian period (794-1185) (accessed Nov 27, 2008).

7 In Java, the teaching of Buddhism and Hinduism is blended during the Singhasari and Majapahit era (and still exist now in Bali) known as Siva-Buddha.

8 Wayang or puppet in Indonesia is a kind of a nickname for any short of stories from Mahabharata and Ramayana.

${ }^{9}$ http://www.bharatayudha.multiply.com/journal/item/108/pandawa_seda (accessed Nov 27, 2008).

${ }^{10}$ See article at "Sekilas Sejarah Komik Indonesia", Matabaca Vol.6/no. 8/ April 2008, 16-18.

${ }^{11}$ Vihara or Kelentheng is a Budhist-Tao-Confucian Shrines. Yang San Sheng, Melawat Ke Alam Neraka Kisah Kejadian Nyata (Semarang: Yayasan Dharma 
Abadi, 2005).

12 This graphical Hells depiction is also very popular in Thailand and Indochina Buddhist. Even, they make it as a public theme park such as Suoi Park in Saigon Vietname, Wat Wang Saen Suk near Bang Saen-Thailand, Tiger Balm Gardens at Singapore, Wat Thawer near Sukhothai-Thaliand, Hua Seng Keng Temple at Kuala Gula Malaysia, and Alu Vihara in Sri Lanka.

${ }^{13}$ E.P. Wieringa, "A Last Admonition to P.P. Roorda van Eysinga in 1828; Haji Zainal Abidin's Syair Alif Ba Ta," Bijdregen tot de taal-, Land en Volkenkunde 154 (1998): 116-28.

${ }^{14}$ Clara Brakel-Papenhuzen, "The Tale of the Skull, an Islamic Description of Hell in Javanese," Bijdragen: Tot de taal-Land en Volkenkunde, 158, (2000): 1-19.

15 Jesus descent into hells is a common tales in Christian tradition.

${ }^{16}$ V.L. Braginsky, Taswsawuf dan Sastra Melayu (Jakarta: RUL, 1993).

${ }^{17}$ http://members.tripod.com/chua_hai_duc/English\%20Sutras/ksitigarbha_ sutra.htm\#Ch05 (accessed Nov 27, 2008).

${ }^{18}$ The notion of Islamic animals-hells are found in Hadiths tradition. See Abu Bakar Abdullah, Sifat Neraka (Jakarta: Pustaka As-sunnah, 2006).

${ }^{19}$ QS. Sād/38: 57-58: "Here is a boiling and an ice-cold draught, so let them taste it, And other (torment) of the kind in pairs (the two extremes)! Here is an army rushing blindly with you."

${ }^{20}$ QS. al-Mursalāt/77: 31-33: "(Which yet is) no relief or shelter from the flame. Lo! it throweth up sparks like the castles, (Or) as it might be camels of bright yellow bue.."

${ }^{21}$ QS. al-Mursalāt/77: 31-33

${ }^{22}$ QS. al-Kahf/18: 29: “... Lo! We have prepared for disbelievers Fire. Its tent encloseth them. If they ask for showers, they will be showered with water like to molten lead which burneth the faces. Calamitous the drink and ill the resting-place!, QS. alAn'àm/6: 70: "... Those are they who perish by their own deserts. For them is drink of boiling water and a painful doom, because they disbelieved". QS. al-Dukhān/44: 43-50. "Lo! the tree of Zaqqum, The food of the sinner! Like molten brass, it seetheth in their bellies. As the seething of boiling water. (And it will be said): Take him and drag him to the midst of hell, Then pour upon his head the torment of boiling water. (Saying): Taste! Lo! thou wast forsooth the mighty, the noble! Lo! this is that whereof ye used to doubt."

${ }^{23}$ This is in Hadith tradition.

${ }^{24}$ QS. al-Anfäl/8: 50-51: "If thou couldst see how the angels receive those who disbelieve, smiting their faces and their backs and (saying): Taste the punishment of burning! This is for that which your own hands have sent before (to the Judgment), and (know) that Allah is not a tyrant to His slaves.".

${ }^{25}$ QS. al-Insān/76: 4: "Lo! We have prepared for disbelievers manacles and carcans and a raging fire.." QS. al-Anfäl/8: 50-51."

${ }^{26}$ QS. al-Ghāsyiyah/88: 1-7: "Hath there come unto thee tidings of the Overwhelming? On that day (many) faces will be downcast, Toiling, weary, Scorched by burning fire, Drinking from a boiling spring, No food for them save bitter thorn-fruit. Which 
doth not nourish nor release from hunger?"

${ }^{27}$ QS. al-Anfầl/8: 50-51.

${ }^{28}$ Umar, M. Ali Chasan, 1978, Abli Neraka dan Kesengsaraannya: digali dari alQur'ān, Toha Putra, Semarang.

${ }^{29}$ Rahmat, Jalaluddin, "Surga dan Neraka: antara perspektif awam dan tassawuf," Al Hikmah (1996) No 16, pp. 50-62.

${ }^{30}$ QS. al-Tahrīm/66: 6: "O ye who believe! Ward off from yourselves and your families a Fire whereof the fuel is men and stones, over which are set angels strong, severe, who resist not Allah in that which He commandeth them, but do that which they are commanded."

${ }^{31}$ QS. al-Tahrīm/66: 9: "O Prophet!' Strive against the disbelievers and the hypocrites, and be stern with them. Hell will be their home, a hapless journey's end." even though Islam beautifully state "For that cause We decreed for the Children of Israel that whosoever killeth a human being for other than manslaughter or corruption in the earth, it shall be as if he had killed all mankind, and whoso saveth the life of one, it shall be as if he had saved the life of all mankind. Our messengers came unto them of old with clear proofs (of Allah's Sovereignty), but afterwards lo! many of them became prodigals in the earth" (QS. al-Māidah/5:32). And slay not the life which Allah hath forbidden save with right. Whoso is slain wrongfully, We have given power unto his heir, but let him not commit excess in slaying. Lo! he will be helped (QS. al-Isrä'/17: 33).

${ }^{32}$ See footnote 22

33 "Lo! as for those whom the angels take (in death) while they wrong themselves, (the angels) will ask: In what were ye engaged? They will say: We were oppressed in the land. (The angels) will say: Was not Allah's earth spacious that ye could have migrated therein? As for such, their habitation will be hell, an evil journey's end."

${ }^{34}$ See footnote 26

${ }^{35}$ QS. al-Jätsiyah/45: 10: "Beyond them there is hell, and that which they have earned will naught avail them, nor those whom they have chosen for protecting friends beside Allah. Theirs will be an awful doom."

${ }^{36}$ QS. al-Tahrīm/66: 9. 